\title{
Commentary
}

\section{How school counselors can help teachers integrate the basic competencies of social and emotional learning}

The purpose of this commentary is to examine how school counselors can assist classroom teachers with the basic competencies of social and emotional learning (SEL), in order to enhance student learning. A brief review of the literature over the past decade reveals that there has been an increase in the number of teachers and schools in general who are utilizing SEL. However, before examining why that has been the case, it is important to discuss what exactly are SEL and the competencies that define it. There are many similar type definitions for explaining SEL but most educators agree that it is basically the process through which students acquire and effectively apply the knowledge, attitudes and skills necessary to understand and manage emotions. Furthermore, it helps students set and achieve goals, feel and show empathy for others, establish and maintain positive relationships and finally to make responsible decisions according to http://casel.org/what-is-sel/ (2019). The core competencies for SEL are: self-awareness; self-management; social awareness; relationship skills; and responsible decision making.

Once there is a basic understanding of SEL, one can see why many educators have decided to implement it at their school sites and how that has increased over the past few years. However, the question of who is involved in implementing SEL and how it is done needs to be more fully explored. Is it simply up to the classroom teacher to implement it or should there be a more collaborative approach? As a former school counselor, I believe it is important for counselors to work closely with teachers on implementing SEL, but this can often be a tricky proposition. Teachers often feel programs like SEL are mandated by site leaders or district administrators and they as teachers have no say so in whether to implement the programs or not. By using a more collaborative approach that involves administrators, school counselors and classroom teachers can help everyone have more buyin into new programs. SEL is no different and should involve all the key stakeholders of a school site, including the school counselors, as by collaborating with teachers provides a learning climate for all students. Many experts (Hensley and Burmeister, 2008) agree that there are multiple approaches to helping students develop SEL competencies but the three most common are: utilizing an evidenced-based SEL curriculum; integrating actual SEL instruction directly into the academic curriculum; and the school or district creating actual SEL-centered policies. This requires educators at a school site to be willing to be change agents, in order to implement programs such as SEL effectively.

Fullan (2001) believed that an effective change agent possesses skills in three main capacities: developing relationships of trust; communicating the change vision effectively; and empowering others to take action toward change. School counselors working directly with teachers to integrate SEL can be visionaries by collaborating with each other. Change agents have not succeeded by working alone but rather building a culture of shared leadership with distributed ownership and common communities of practice (Trybus, 2011). To implement SEL to its optimal effectiveness, this building of common communities of practice is essential.

(C) Ronald Dennis Morgan. Published in Journal of Research in Innovative Teaching \& Learning. Published by Emerald Publishing Limited. This article is published under the Creative Commons Attribution (CC BY 4.0) licence. Anyone may reproduce, distribute, translate and create derivative works of this article (for both commercial and non-commercial purposes), subject to full attribution to the original publication and authors. The full terms of this licence may be seen at http://creative commons.org/licences/by/4.0/legalcode

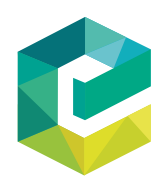

Journal of Research in Innovative Teaching \& Learning Vol. 12 No. 2, 2019 pp. $109-110$ 
JRIT\&L 12,2

Hence, from a practical approach, how can school counselors help teachers in both implementing and promoting SEL at their school site? There are a number of ways for school counselors to be involved in this process, but helping with the five competencies of SEL is probably the most effective, since these are inherently part of a counselor's expertise. School counselors typically work with students in the five competency areas, so helping teachers implement these in the classroom, as part of SEL curriculum, is a natural fit. With many of today's youth facing complex demands, academically, personally and socially, it has never been more important for schools to implement a SEL curriculum. Involving school counselors in this process will help teachers better understand the essential components of SEL and how they can better provide skills to students for addressing the many issues they face in the twenty-first century.

\section{Ronald Dennis Morgan Educational Administration, School Counseling and School Psych, National University, Costa Mesa, California, USA}

\section{References}

Fullan, M. (2001), Leading in a Culture of Change, Jossey-Bass, San Francisco, CA.

Hensley, P. and Burmeister, L. (2008), Leadership Connectors: Six Keys to Developing Relationships in Schools, Eye on Education, Larchmont, NY, available at: http://casel.org/what-is-sel/ (accessed 2019).

Trybus, M.A. (2011), "Facing the challenge of change: steps to becoming an effective leader", Delta Kappa Gamma Bulletin, Vol. 77 No. 3, pp. 33-36.

\footnotetext{
About the author

Dr Ronald Dennis Morgan is Associate Professor at National University. His research has explored: Youth social issues, the identity/roles of school counselors, social justice issues, educational change agents and the school counselor's role in social and emotional learning. His research has culminated in book chapters, journal articles and numerous conference presentations. Dr Ronald Dennis Morgan can be contacted at: Rmorgan2@nu.edu
} 